\title{
ESTIMASI KEBISINGAN PEMUKIMAN PADAT PENDUDUK DI SEKITAR BANDARA STUDI KASUS : BANDARA HALIM PERDANAKUSUMA
}

\author{
Chintya Rahmahtillah Edwin, Mufti Arifin, Aprilia Sakti K \\ Prodi Teknik Penerbangan, Fakultas Teknologi Kedirgantaraan,Universitas Suryadarma Komplek \\ Bandara Halim Perdanakusuma, Jakarta 13610, Indonesia \\ Corresponding Author: chintyarahmah3@gmail.com
}

\begin{abstract}
Abstrak - Bandara Halim Perdanakusuma sebagai tempat pertemuan segala aktivitas penerbangan merupakan salah satu sumber yang berpotensi mencemari udara terutama dalam hal kebisingan, dimana hal tersebut dapat mengganggu aktivitas warga sekitar. Banyak faktor yang mempengaruhi pada efek kebisingan terhadap gangguan masyarakat seperti, tingkat suara, durasi, waktu kejadian, jangka kebisingan. Penelitian ini bertujuan untuk mengetahui intensitas kebisingan disetiap titik yang telah ditentukan didaerah pemukiman sekitar bandara Halim Perdana dan menentukan batas kawasan kebisingan pemukiman sekitar menurut Keputusan Menteri Perhubungan No.48 tahun 2002 menggunakan metode perhitungan WECPNL. Alat ukur yang digunakan pada penelitian ini hanya alat ukur kebisingan yang disebut sound level meter. Dalam hasil pengolahan data nilai indeks WECPNL dengan intensitas kebisingannya yaitu jarak 200 meter dengan indeks WECPNL sebesar 74,1 dB, jarak 1000 meter dari ujung landasan pacu 06 dengan indeks WECPNL sebesar 80,7 dB, jarak 1000 meter dari ujung landasan pacu 024 dengan indeks WECPNL sebesar 75,5 dB. Kebisingan pada Bandar Udara Halim Perdanakusuma masih sesuai dengan Keputusan Menteri Perhubungan No. 48 Tahun 2002 dimana dari hasil indeks WECPNL yang dimana terdapat pada kawasan kebisingan tingkat 3 yaitu pada JI. AMD XII, kawasan kebisingan tingkat 2 yaitu pada Jl. Radar Utara, dan kawasan kebisingan tingkat 1 yaitu pada J.Kampung Baru 1.
\end{abstract}

Kata Kunci: Kebisingan, Sound Level Meter, Indeks WECPNL

Abstract - Halim Perdanakusuma Airport as a meeting place for everything flight activity is one potential source pollutes the air especially in terms of noise where it is can interfere with activities of local residents. Many factors are influence on the effect of noise on community distrubance such as, sound level, duration, time of incident, duration of noise. This study aims to determine the intensity of noise in eac designated point in the residential area around Halim PerdanaKusuma Airport and define the boundaries of the residential noise area around according to the Decree of the Minister of Transpotation No.48 of 2002 using the WECPNL. Calculation method measuring tool used in this study only a noise measuring instrument called a sound level meter. In the results of data processing the WECPNL, index value with the noise intesity is a distance of 200 meters with the WECPNL index amounting to 74,1 dB, a distance of 1000 meters from the end of runway 06 WECPNL index of 80,7 dB, a distance of 1000 meters from the end of the runway 024 with a WECPNL index $f$ 75,5 dB. Noise o Halim Perdanakusuma Airport still in accordance with the Decree of the Minister of Transpotation No.48 of 2002 where from the index results WECPNL where 3 is in the noise level 3 area namely on JI. AMD XII, noise area level 2 nmely on Jl. Radar Utara, and the noise area level 1 is on Jl. Kampung Baru 1.

Keyword: Noise, Sound Level Meter, WECPNL Index 


\section{PENDAHULUAN}

Dengan perkembangan dunia penerbangan dan mobilitas manusia serta barang yang semakin tinggi, maka fungsi bandar udara menjadi semakin penting. Bandar udara Halim Perdanakusuma sebagai tempat pertemuan segala aktivitas penerbangan merupakan salah satu sumber yang berpotensi dalam mencemari udara terutama dalam hal kebisingan. Jumlah penerbangan domestik di Bandara Halim Perdanakusuma setiap harinya mencapai sekitar 160 penerbangan, Maksimal penerbangan takeoff dan landing di Bandara Halim Perdanakusuma 12 penerbangan per jam. Akibatnya kebisingan semakin mengganggu dan memberikan dampak buruk pada kesehatan. Namun sumber kebisingan tidak hanya dari bandar udara saja namun dapat berasal dari lingkungan sekitar yang terkait dengan aktifitas manusia sehari-hari.

Di daerah padat penduduk seperti perkotaan, bising merupakan salah satu masalah yang harus dihadapi masyarakat setiap hari. Kebisingan adalah bunyi yang tidak diinginkan dari usaha atau kegiatan dalam tingkat dan waktu tertentu yang dapat menimbulkan gangguan kesehatan manusia dan kenyamanan lingkungan.

Banyak faktor yang mempengaruhi efek kebisingan terhadap gangguan masyarakat seperti tingkat suara, durasi, waktu kejadian, jangka kebisingan. Kebisingan sendiri dapat berdampak mengganggu kemampuan seseorang untuk tidur, mengurangi durasi tidur, mengurangi kualitas tidur, membangunkan orang saat tidur dan meningkatkan gerakan tubuh selama tidur.

Kebisingan merupakan bunyi yang tidak diinginkan dari suatu usaha atau kegiatan dalam tingkat dan waktu tertentu yang dapat menimbulkan gangguan kesehatan manusia dan kenyamanan lingkungan ${ }^{[1]}$. Kebisingan pada bandara bersumber pada pesawat yang sedang dioperasikan atau sedang dalam perawatan, besarnya kebisingan yang sampai pada objek tergantung pada jarak atau sumber kebisingan.

Standar alat ukur yang digunakan untuk mengukur kebisingan adalah Sound Level meter (SLM). Biasanya alat ini digunakan untuk mengidentifikasi tempattempat yang tingkat kebisingannya lebih tinggi dari aturan batas maksimum ${ }^{[2]}$. Adapun prinsip kerja dari alat SLM adalah apabila terjadinya suatu getaran yang bersumber dari aktivitas manusia dan yang lainnya, hal ini akan menimbulkan perubahan tekanan udara yang mana perubahan tersebut akan direspon oleh alat SLM.

Berdasarkan keputusan Menteri Perhubungan nomor 48 tahun 2002 tentang penyelenggaraan bandar udara umum bahwa tingkat kebisingan ditentukan berdasarkan metode Weightened Equivalent Continuous Perceived Noise Level (WECPNL), metode ini berdasarkan standar dari International Civil Aviation Organization (ICAO). WECPNL ini adalah indeks kebisingan yang dimana untuk menghitung paparan kebisingan total selama periode 24 jam.

Setiap bandara dan lingkungan di sekitarnya memerlukan pengaturan dan pengendalian tata ruang dan penggunanaan tanah. Untuk pengaturan dan pengendalian tersebuat maka dibuat batas kawasan bising untuk bandar udara. Batas Kawasan Bising adalah kawasan tertentu di sekitar bandara yang terpengaruh oleh bising operasi pesawat udara saat pemanasan mesin, taxiing, mendarat, lepas landas, serta melintas yang dapat mengganggu lingkungan.

Menurut keputusan Menteri Perhubungan No. KM 48 tahun 2002 tentang Penyelenggaraan Bandar Udara Umum, batasan kawasan kebisingan di sekitar bandara yang terpengaruhi oleh gelombang suara mesin pesawat udara. 
Berikut adalah tabel batas kawasan kebisingan.

Tabel 1 Batas Kawasan Kebisingan ${ }^{[3]}$

\begin{tabular}{|c|c|}
\hline Kawasan Kebisingan & Indeks WECPNL \\
\hline 1 & $70 \leq \mathrm{WECPNL}<75$ \\
\hline 2 & $75 \leq \mathrm{WECPNL}<80$ \\
\hline 3 & WECPNL $\geq 80$ \\
\hline
\end{tabular}

Berdasarkan uraian di atas, maka perlu dilakukan penelitian tentang analisis estimasi kebisingan di pemukiman padat penduduk sekitar bandara Halim Perdanakusuma. Penelitian ini bertujuan untuk mengetahui besar kebisingan di 3 titik yang telah ditentukan sekitaran pemukiman bandara Halim Perdanakusuma dan menentukan pembagian batas kawasan kebisingan. Alat ukur yang di gunakan pada penelitian ini adalah Sound Level Meter, Stopwatch dan Global Positioning System (GPS).

\section{METODE PENELITIAN}

Penelitian ini dilakukan selama 1 hari (24 jam) dan diukur ditiga titik lokasi pemukiman yang berada didekat Bandara Halim Perdanakusuma. Dimana setiap lokasi penelitian ditentukan dengan jarak $200 \mathrm{~m}$ sejajar dengan landasan pacu 06, $1000 \mathrm{~m}$ dari ujung landasan pacu 06 serta 1000 m dari ujung landasan pacu 024. Adapun penelitian ini dilaksanakan 3 hari pada tanggal 16-18 Juni 2020 dilakukan secara kerja sama bersama Bramantio Wijaya Syahputra (NPM : 16010027). Dengan titik lokasi pertama adalah Jl. Kampung Baru 1 sejajar dengan landasan pacu 06, Jl. Amd XII sejajar dengan ujung landasan pacu 06, dan Jl. Radar Utara sejajar dengan ujung landasan pacu 024.

\subsection{Bahan}

Data nilai tingkat kebisingan diambil pada tiga titik yang telah ditentukan didaerah pemukiman padat penduduk sekitar bandara Halim Perdanakusuma saat kendaraan umum beraktifitas seperti pesawat, kendaraan umum, dan aktivitas warga disekitar pemukiman tersebut.

\subsection{Alat}

Alat yang digunakan pada penelitian ini adalah SMART SENSOR Sound Level Meter AS804, yang memeliki spesifikasi sebagai berikut :

Tabel 2.1 Spesifikasi Sound Level Meter

\begin{tabular}{|l|l|}
\hline Measuring Range & $30-130 \mathrm{~dB}$ \\
\hline Accuracy & $\pm 1,5 \mathrm{~dB}$ \\
\hline Resolution & $0,1 \mathrm{Db}$ \\
\hline $\begin{array}{l}\text { Frequency } \\
\text { Response }\end{array}$ & $31,5 \mathrm{~Hz}-8 \mathrm{KHz}$ \\
\hline
\end{tabular}

\subsection{Teknik Pengukuran}

Pengukuran dilakukan setiap kali ada pesawat yang landing dan take-off sesuai dengan schedule penerbangan dalam 1 hari pengukuran, yaitu mulai pukul 07.00 sampai dengan 04.00 WIB. Alat ukur diletakkan pada tongkat dengan ketinggian $\pm 2 \mathrm{~m}$ dari permukaan tanah. Alat ukur dikalibrasi setiap akan melakukan pengukuran agar mendapatkan hasil yang akurat. Pengukuran dilakukan setiap 1 jam dengan pengukuran selama 3 menit dan pembacaan kebisingan setiap 5 detik. Hasil pengukuran dan waktu saat melakukan pengukuran kemudian dicatat.

\section{HASIL DAN PEMBAHASAN}

\subsection{Tingkat Kebisingan Berdasarkan} Jenis Pesawat

Jenis-jenis pesawat terbang yang diukur kebisingannya dari hasil pengukuran intensitas kebisingan pesawat yang dilakukan terdapat 4 tipe jenis pesawat terbang yang beroperasi, yaitu jenis pesawat Boeing 737 series, Airbuss A320 series, Hercules, dan CN-235.

\subsection{Pengukuran Weighted Equivalent Countinous Perceived Noise Level (WECPNL)}

Untuk mendapatkan nilai WECPNL, perlu dilakukan perhitungan untuk 
mendapatkan hasil DL dan NL dengan rumus sebagai berikut :

$\mathrm{DL}=10 \log \frac{1}{16}\left(10^{0,1} \mathrm{~L}_{1}+\ldots+10^{0,1} \mathrm{~L}_{4}\right) \mathrm{dB}$.

$N L=10 \log \frac{1}{8}\left(10^{0,1 L_{5}}+\ldots+10^{0,1 L_{7}}\right) d B$.

Setelah ditemukannya nilai DL dan $\mathrm{NL}$ maka kedua nilai ini dimasukkan kedalam rumus WECPNL, dimana WECPNL ini adalah indeks kebisingan yang dimana untuk menghitung paparan kebisingan total selama periode 24 jam. Berikut ini nilai DL dan NL yang telah diketahui yaitu :

Tabel 3.1 Nilai DI dan NL

\begin{tabular}{|c|c|c|}
\hline Lokasi & Nilai DL & Nilai NL \\
\hline 1 & 71,2 & 45,7 \\
\hline 2 & 77,8 & 45,7 \\
\hline 3 & 72,5 & 55,3 \\
\hline
\end{tabular}

Oleh karena itu, untuk mendapatkan nilai indeks kebisingan WECPNL untuk setiap titik yang ditentukan maka menggunakan rumus seperti dibawah ini : $L_{W E C P N}=10 \log \left[\frac{5}{8} 10^{\frac{L_{E C P N_{d}}}{10}}+\frac{3}{8} 10^{\frac{L_{E C P N_{n}}}{10}}\right]+s \ldots \ldots \ldots \ldots . .(2.8)^{[4]}$

Dimana $\mathrm{L}_{\mathrm{ECPN}_{\mathrm{d}}}$ adalah ECPNL selama waktu siang hari, dan $\mathrm{L}_{\mathrm{ECPN}_{\mathrm{n}}}$ adalah ECPNL selama waktu malam hari. Serta $s$ adalah nilai faktor bobot musiman. Kemudian Nilai pada tabel dimasukan pada rumus WECPNL, sehingga didapatkan nilai WECPNL pada masingmasing lokasi sebagai berikut :

Tabel 3.2 Nilai WECPNL Pada Setiap Titik

\begin{tabular}{|c|c|c|c|}
\hline Titik & Lokasi & $\begin{array}{c}\text { Jarak dari } \\
\text { Landasan } \\
\text { Pacu } \\
(\mathrm{m})\end{array}$ & WECPNL \\
\hline 1 & $\begin{array}{c}\text { Jl.Kampung } \\
\text { Baru 1 }\end{array}$ & $200 \mathrm{~m}$ & 74,1 \\
\hline 2 & Jl.Amd XII & $1000 \mathrm{~m}$ & 80,7 \\
\hline 3 & $\begin{array}{c}\text { Jl.Radar } \\
\text { Utara }\end{array}$ & $1000 \mathrm{~m}$ & 75,5 \\
\hline
\end{tabular}

\subsection{Analisis Indeks Weighted Equivalent Continous Perceived Level (WECPNL)}

Pada Tabel 3.2 diatas dapat di analisis bahwa perbandingan kebisingan setiap titik lokasi, dimana lokasi kedua memiliki kebisingan yang lebih tinggi dikarenakan pemukiman pada titik tersebut dekat dengan akses jalan tol jagorawi, sehingga kebisingan pada lokasi tersebut sudah sangat tercemar karena banyak nya kendaraan bermotor pada lingkungan penduduk, mobil yang melintas pada jalan tol dan lalu lalangnya pesawat yang melintas dipemukiman membuat warga setempat terganggu dengan kebisingan yang didapat.

Pada lokasi ketiga memperlihatkan besar kebisingan pada lingkungan ini tidak tinggi seperti titik pertama namun tidak rendah seperti titik pertama, dikarenakan pemukiman ini terletak dekat jalan besar yang dimana banyak kendaraan umum melintas. Sehingga bising dari pesawat yang diterima oleh masyarakat tidak terlalu mengganggu aktifitas warga sekitar. Namun kebisingan dari kendaraan yang melintas cukup mengganggu aktifitas warga dipemukiman ini.

Pada tabel tersebut juga terlihat bahwa lokasi titik pertama lebih rendah kebisingannya dikarenakan pada pemukiman ini jarang sekali kendaraan yang melintas dikarenakan kecilnya akses pemukiman sehingga bising yang didapat dari pesawat sangat besar pada lingkungan ini yang dimana pemukiman terletak disepanjang landasan pacu 06. Sehingga penduduk sekitar merasa terganggu karena adanya pesawat yang selalu melintas pada titik ini.

\subsection{Pembagian Batas Kawasan Kebisingan}

Pada Tabel 1 memperlihatkan pembagian kawasan kebisingan dimana sesuai dengan Keputusan Menteri Perhubungan No.48 Tahun 2002 tentang Penyelenggaraan Bandar Udara Umum, dimana pada tabel tersebut menjelaskan Keputusan Menteri Perhubungan No. 48 tahun 2002 tentang batas kawasan kebisingan disekitar bandara yang terpengaruhi oleh kebisingan indoor dan outdoor. Tabel 3.2 menunjukan bahwa Jl. 
Kampung Baru 1 termasuk dalam batas kawasan kebisingan tingkat 1, Jl. Amd XII termasuk ke dalam batas kawasan kebisingan tingkat 3, dan JI. Radar Utara termasuk dalam batas kawasan kebisingan tingkat 2.

\section{KESIMPULAN}

Kesimpulan yang diperoleh adalah pada lokasi 1 pada Jl. Kampung Baru 1 menerima kebisingan secara terus menerus sebesar 74,1 kemudian pada JI. AMD XII diperoleh kebisingan sebesar 80,7 dan pada Jl. Radar Utara memperoleh kebisingan sebesar 75,5. Dari hasil-hasil tersebut dapat disimpulkan bahwa Jl. Kampung Baru 1 termasuk dalam kawasan kebisingan tingkat 1, Jl. Radar Utara termasuk dalam kawasan kebisingan tingkat 2 dan JI. AMD XII termasuk kawasan kebisingan tingkat 3.

\section{DAFTAR PUSTAKA}

(1) KepMen LH RI No.48., 1996, Baku Tingkat Kebisingan, Jakarta.

(2) Suma'mur, P.K., 1984, Higene Perusahaan dan Kesehatan Kerja (Cetakan-4). Jakarta : Gunung Agung.

(3) KepMenHub No.48., 2002, Batas Kawasan Kebisingan. Jakarta.

(4) Rujigrok, G.J.J., 1993., Elements Of Aviation Acoustics. Delft University Press. Netherlands. 